\title{
Introduction on the Female Image of Becky in Vanity Fair
}

\author{
Xia Zhang, Lin Cheng \\ School of Foreign Languages of Mianyang Normal University, China
}

Keywords: Vanity Fair; Becky; feminism.

\begin{abstract}
William Makepeace Thackeray is a great critical novelist in English in the nineteenth century. Vanity Fair is generally acknowledged as his most remarkable masterpiece, which makes him well known around the world. In the novel, the female images are endowed with vivid personalities, especially the character Becky Sharp, which enchants appreciation from a great deal of students. It is acknowledged that the female image in Vanity Fair has a dual character-viciousness and virtuousness. Becky is dehumanized from the perspective of her tucking into the upper class at all costs, but from the angle of view that she endeavors to achieve a better life, she deserves compliment. She seeks after wealth and fame, she is self-concerned and lives a fairly life, but she is struggling to change her destiny. This article analyses Becky's negative image at first, then pays more attention to the feminism of Becky's image under two parts: characters and differences on traditional women roles, and finally concludes Becky's image and its' enlightenment on modern society.
\end{abstract}

\section{Introduction}

Vanity Fair is the masterpiece of Makepeace Thackeray and makes him well known around the world, it is also a marvelous work in English literature. In this novel, the female imagine is essential to comprehend the implict criticism of an unfair reality. Furthermore, the female imagine is the outcome and victim of the society.

In this novel, two girls show us different choices on life. The lovely and kind girl Ameilia Sedley, who doesn't esteem the values of Vanity Fair and Becky Sharp who cares nothing for else. Becky is a person with vivid personalities. She is born in a poor family; her father is incompetent so that Becky needs to protect her family. Absolutely Becky is an unlucky one, she has no family, no money, no protector, but she never bows to difficulties and tries to change life at all costs. There is no point that Becky is a devil, she cheats everyone and exploits others for her own profit. She takes advantage of her beauty to attract the nobility in order to improve her own society state and tuck into upper class, she enjoys the feeling of money and fame, only in this way can she has a feeling of safety. But as a lower class people, Becky dares to struggle and fight against the world, she changes her destiny by herself and always keeps optimistic towards life no matter what she meets in life. Her image reflects feminism very well and attracts many people to study.

This article analyzes Becky's image from her bad and good angel as well and pays more attention to Becky's positive side. Becky's image shows us a vivid and characteristic personality. The spirit of feminism plays an important role in her image and it also encourages us to pursuit freedom and equal rights in modern society as well.

\section{Bad view of Becky's image}

In Becky's life, the world is governed by money, it's a 'market', in this market, people can betray everything for fame and wealth. In order to tuck into upper-class Becky cheats and betrays a lot. In her mind, everything is worthwhile to achieve her ambition. She is scheming, changeable, vainglorious and selfish, and these are the points which make people dislike her.

A scheming woman. Becky is a scheming girl, she is good at disguising herself to be what people likes, in others' eyes, she is beautiful, generous and gentle. Becky cares no one except herself, but in order to cheer others, she pretends to be a kind woman. As a mother, she is never concerned with her 
only son, but pretends to be a good mother and kisses her son in public. As a wife, she doesn't love her husband and only regards him as a servant, but pretends to be a gentle wife and looks after her husband carefully. She pretends to care about his safety in wars and plans everything for earn him, the poor man is satisfied with his wife and even loses his right to inheritance without gripe. As a close friend, she lets her husband to cheat Ameilia and her husband's money, but when she faces with Ameilia, she plays a kind role again.

A changeable woman. Becky plays various roles seriously, holds different attitudes toward different people and makes a success in the Vanity Fair. Becky does well not only in camouflaging herself but also in adapting at different circumstances. She is quiet changeable. When Becky is invited to visit Ameilia's family, she acts in a weak way. When Becky begins her life at Queen's Crawley, she quickly becomes an important role in this family, in this family, Becky changes again. When faces with two girls, Becky asks them to educate themselves in the way they like. Mr. Crawley is a very religious man, when faces with him, she asks him about French books and talks on religious matters. When she faces with her employer, Becky reads all the law papers and his letters. When faces with Miss Crawley, an annoying woman, Becky still quickly wins the heart of that bad old woman.

A vainglorious woman. In Becky's world, fame and wealth are everything, she would never let a chance off, she would try her best to cater to people who is helpful to her. Miss Crawley has seventy thousand pounds, so Becky talks with her on what she likes best, when Miss Crawley gets ill, Becky comes to London to look after her and cheer her up.

As Becky's husband, Rawdon doesn't have a good job, they have no income at all, but out of people's surprise, she lives very well. She holds different parties in home and applies good dinners to guests, even their friends are confused that how it is possible to live so well on an income of nothing a year. When they return to London, they rent an apartment. The dinners at this house are always wonderful and cheerful, the sitting rooms are very pretty, Becky never stops enjoying luxury life no matter she has money or not.

A selfish woman. Becky is a selfish one in deed. She prefers to own profit rather than others. She has friends and family, but if she has to make a choice, it can be no doubt that she will choose herself.

In Rawdon's mind, his wife is a clever woman, he doesn't need to worry a lot about life. At first Becky chooses him just because he can give her the wealth, the fame and the chance to into the upper-class, so she takes actions quickly not because of love. When Rawdon is going to the war, he worries about Becky, unfortunately, all Becky cares about is herself.

Like other upper-class people, she doesn't take notice of common people. Before she leaves Paris, people all know that the couple will have large number of legacy. She arranges new home and buys watches and jewels without paying. And she never goes back agai n. Becky grows up in a poor family too, she knows the situation of poor people, but she still cheats them just for the sake of enjoying her life.

\section{Becky's feminism and reversals on traditional roles}

It has attracted many people since the novel Vanity Fair was published. Someone holds the view that Becky's image reflects the hypocritical upper class and the value of money first. Besides, someone holds the view that Becky's image reflects the feminism of the society. She makes great efforts to change her destiny continually. It's a subversion of traditional women image.

\subsection{Characters of Becky}

Becky is born in poor, so she has to study and work in Miss Pinkerton's school. Although she is clever and beautiful, Becky is still looked down by headmistress and rich girls because of her poor family. She isn't satisfied with her status, so she decides to struggle with the society. Absolutely, Becky's experience tells her that she can't change life by herself, the best way to change life is a marriage, a suitable marriage.

Becky is a brave woman who opposites with traditional women images, she wants to have equal rights with man. As a woman without any background, she keeps fight against society and tries to change her destiny. Contrary to traditional roles, Becky's image changes a lot from weak to robust. 


\subsection{The role of marriage}

For most women, marriage is an important thing, as the man they choose is the one to rely on in future, they have various dreams about marriage and love, but for Becky love is different.

After leaves school, Becky realizes that there is no hope for a poor girl to live in this male-dominated society, the best reliable and useful way to change her life is marriage. With this aid, she becomes an actress, and pretends to be what other people like. When she meets Joseph, she pretends to admire him and acts like an 'ideal women' to attract Joseph,

When Old Crawlay expresses his thought to marry her, Becky feels regret about it as she has married his son Rawdon in privacy. The reason why Becky chooses Rawdon and even dares to marry him in privacy is obviously, Rawdon has the tremendous possibility to inherit a large number of legacy, it's the perfect choice for Becky to become a rich women, so she gets married desperately.

\subsection{The role of family}

As a woman who runs for self-liberation and freedom, Becky plays a leading role in family, and it is also the strong symbolize of feminism. In Becky and Rawdon's real life, Becky still plays a necessary role in her family and even takes more responsibility in their life. Rawdon never carries the burden for family and only does what his wife tells him to do. she tries her best to earn money, even the way she gets money is not well, she is still the leader in her family and enjoys to be a leader in life. Becky becomes the master in family and Rawdon becomes the servant of Becky, it's also contrary to traditional female image in Patriarchal society.

\subsection{The role of mother}

In Becky's memory, she doesn't know what the character-mother should do as she takes care of herself and grows up by herself. So it is not hard to understand why Becky has no idea to cope with her son, during her life no one teaches her how to treat children and how to express love towards children.

It's a great pity that the emotion between mother and son is so poor. In little Rawdon's eyes, mother is a beautiful woman but he can't touch her. He doesn't has much feeling towards his mother and prefers to stay with his nurse. After Rawdon abandons her, she never thinks of taking any steps to deal with her son. Until Sir Pitt's only boy dies, little Rawdon becomes the heir of Queen's Crawley. She writes the most affectionate letter to her son in hope of benefiting from him. Finally, his son declines to see her, but makes a liberal allowance.

There isn't any shadow of traditional mother in Becky's image, but it's hard to judge whether she loves her son or not. Becky is not a good mother, it is due to her pursuit to freedom and equality in her family and society. In such a society, women are restrained by too much rules and women's rights are lack of protection, so Becky needs to pay a lot for her dream into upper-class, while men could achieve this easily. Traditional mothers like Amelia, they regard children as their whole life and pay much attention to their children however Becky has to spend this energy and time to govern her family, and plays a role which lacks of love, it's the cost of equality and it's also the subversion of traditional mother's image.

\section{Conclusion}

The Vanity Fair exposes and criticizes the bourgeois society in19th century, it regards the whole society as a market which is full of fame and wealth. Characters appearing in this novel just like merchants which could exchange everything for money and status. Becky Sharp is the most successful character in Vanity Fair and is also the most representative merchant in the market, she is born in poor and lives in hard environment, she lacks of background and without strong supporter, she is merely a common woman in society. In the society of 19th century, women are still in a unfair status, it is still hard for an inferior woman to possess power and authority, so Becky pays much for her dream to upper-class. Her friendship, her husband, and her son, all of these are sacrificed for her desire. The cost of success is huge, but as the writer says in the last of novel, "Vanitas vanitatum! 
Which of us is happy in the world? Which of us has his desire? Or, having it, is satisfied?” (Makerpeace.2001:287).

All fame is in vain, only the spirit will immortal. Through Vanity Fair it can be found that Becky is an ambitious schemer in people's eyes, but what is more important is her positive side. She is intelligent and brave, she always keeps optimistic towards tough environment, and achieves her success in her way, she is the winner. Her image embodies the reversals on traditional women's weak image. There are so many poor women in the world, they tolerate and accept the suffering, but Becky is different, she dares to fight against the world, she dares to release her desire of wealth, she could try her best to achieve her dream, she never hides her strong desire to upper-class. Although she betrays and loses a lot, but she still gets she want in the end, she is still successful in her life.

Nowadays, more and more women are fighting for women rights in culture, economic and politics during the global world, absolutely the world has got rid of many corrupt customs but there are still some bad behaviors in poor areas. From Becky it can be learned that women should be knowledgeable and have own opinions towards the world. Women should never give up themselves, no matter what time goes on. You can't please everyone, so you've got to please yourself.

The question how a woman should live in life can be concluded with a simple but intriguing sentence by Simone de Beauvoir, "One is not born, but rather becomes woman."(Beauvoir.1973). Women can't change the whole environment but can become the one who is respected.

\section{References}

[1] Harden, F, Edgar. Thackeray the Writer: From Journalism to Vanity Fair. [M]. London: Macmillan Press Limitd, 1998.

[2] Harry, Blamers. A short history of English Literature. [M]. London: The Chaucer Press Limited,1984.

[3] Jia Weiwei. A feminist interpretation of Becky Sharp in Vanity Fair. [D]. Shandong: Shandong University,2009.

[4] Jadwin, Lisa. The Seductiveness of Female Duplicity in Vanity Fair. [J]. Studies in English Literature, 1992.

[5] Thackeray, Makepeace. Vanity Fair. [M]. London: Wordsworth Editions Limited,2001.

[6] Xu Xulin. Women in the Eyes of Thackeray. [D]. Wuhan: Central China Normal University,2005. 